\title{
NEW FUTURES, SAME OLD FEARS: GENDER-BASED VIOLENCE AND COPING STRATEGIES IN CONTEMPORARY YOUNG ADULT DYSTOPIAN FICTION
}

NUEVOS FUTUROS, VIEJOS TEMORES: VIOLENCIA DE GÉNERO Y EL PROCESO DE SUPERACIÓN DE LAS VÍCTIMAS EN LA DISTOPÍA JUVENIL CONTEMPORÁNEA

\author{
Andrea Burgos-Mascarell \\ Universitat de Valencia \\ andrea.burgos@uv.es \\ 0000-0001-6344-1389
}

\begin{abstract}
The ability of dystopian fiction to offer critical views of futures riddled with the devastating consequences of today's failures is pervasive also in its literary subgenre targeting young readers. While scholarship on these novels is extensive, the prevalence of sexual assaults in this subgenre requires attention. This study offers an introductory analysis of two contemporary young adult dystopian trilogies, Veronica Roth's Divergent (2011-2013) and Beth Revis' Across the Universe (2011-2013), with a focus on the sexual assaults the protagonists endure. The discussion draws on trauma and sexual abuse research to ascertain how and if these future societies and heroines challenge traditional representations of this crime.
\end{abstract}

Keywords: dystopian fiction, young adult, sexual assault, postfeminism, trauma, culture

\section{Resumen}

La habilidad de la ficción distópica para ofrecer visiones críticas de futuros impregnados de las devastadoras consecuencias de los errores del presente se manifiesta también en su subgénero literario para jóvenes lectores. A pesar de que la investigación sobre estas novelas es extensiva, la prevalencia de las agresiones sexuales en el subgénero requiere atención. Este estudio ofrece un análisis introductorio de dos trilogías juveniles distópicas contemporáneas, Divergent de Veronica Roth (2011-2013) y Across the Universe de Beth Revis (2011-2013), centrado en las agresiones sufridas por las protagonistas. El desarrollo del mismo se basa en investigación sobre el trauma y el abuso para determinar cómo, si es el 
caso, estas sociedades futuras y sus heroínas desafían las representaciones tradicionales de este crimen.

Palabras clave: ficción distópica, juvenil, abuso sexual, posfeminismo, trauma, cultura

\section{Introduction}

Dystopian fiction has dealt with humanity's fears since its inception. Those fears range from technological disaster, ecological apocalypse, generalized violence and repression to emotional torture or group-specific violence, including racism or gender violence. When one considers feminist dystopian fiction, Margaret Atwood's The Handmaid's Tale (1985) is usually one of the first titles that come to mind. Her ultraconservative dystopian society limited women's roles to the puritan wife, the servant, and the vessel of life, egregious objectifications of women that had their most aggressive representation in the systematic and institutionalized rape of handmaids with the objective of procuring the privileged class with offspring. Apart from the physical damage rape causes, this crime also implies a subduing and disempowerment of the victim, as in Atwood's novel, aggravated by oppressing social structures. Rape is thus a power mechanism and only the executive part of an entire culture of oppression of women's bodies (Williams). However, rape is only one of the multiple representations of sexual assault, which is considered to include "any nonconsensual sexual act proscribed by Federal, tribal, or State law, including when the victim lacks capacity to consent" (The United States Department of Justice).

While the threat of sexual assault has been present directly or indirectly in utopian and dystopian fiction for centuries, as in the creation of segregationist communities where women could be safe from those aggressions, the second wave of the feminist movement was key to fighting the taboo of speaking about traumatic sexual experiences including rape and to spread criticism of sexual assault. Up until then, the conceptions and representations of sexual assault had remained mostly unchallenged. In the context of contemporary dystopian fiction, Ira Levin's This Perfect Day (1970) includes a scene where the male protagonist rapes his love interest while demanding her to submit and calm down. After the act, not only does the victim remain with the aggressor, but she justifies his behaviour as natural and finally marries him. The novel lacked any overt criticism or punishment of the protagonist for the crime; furthermore, the victim, who had previously been an active member of a rebellious group and had pointed the 
protagonist into the right direction to find possible safe havens, goes on to become a voiceless decorative character, absolutely devoid of her previous agency. The change can be read, indeed, as a representation of the destructive effect rape has on the victims' identity and self-confidence and of the impunity some aggressors enjoy particularly within the domestic sphere. By contrast, the feminist utopias of the 1970s resisted and denounced these representations of sexual aggression disguised as part of a romantic relationship by including physically enhanced female protagonists, empowered through technology, such as Joanna Russ' cyborg in The Female Man (1975), or by building a genderless utopia where violence was no longer a threat and the power interactions were rendered worthless, as in Woman on the Edge of Time (1976) by Marge Piercy. The novels published in the 1980s and 1990s again introduced sexual assault as an inevitable additional threat to women's safety in post-apocalyptic worlds like Octavia Butler's Parable of the Sower (1993), thus resisting as a constant in an otherwise highly diverse genre of speculative fiction.

The inclusion or discussion of these crimes in novels considered to foster critical thinking among readers may have a clear purpose, as in the critical feminist dystopias mentioned above, but it may also be reduced to a mere plot resource. According to Reid and Finchilescu, "exposure to media aggression against women heightens feelings of disempowerment in female viewers" (397), which stresses the importance of treading carefully when including such scenes in cultural products. Considering the recent popularity of dystopian fiction among young adults, how are those texts dealing with this prevailing heinous crime? Do those texts challenge passive representations of this kind of abuse or do they include them as a mere narrative tool to arouse emotion in readers? This study aims at exploring the representation of gender-based aggressions in YA dystopian fiction with a focus on sexual assault attempts both as the main act of violence and as additional denigrating acts through a close reading of the texts. The two trilogies explored are US young adult dystopian novels: Beth Revis' Across the Universe and Veronica Roth's Divergent, both published between 2011 and 2013. The next section provides an overview of dystopian fiction and of research on approaches to the subgenre's latest wave of popularity with novels aimed at a younger audience. The discussion is based on the close reading of the novels and introduces a dialogue with research on trauma studies and the "problem novel" to ascertain whether young adult dystopian novels differ from or relate to traditional approaches to this kind of violence. The analysis will focus on three aspects: the societal structures that enable the act, the victims' coping mechanisms, and the societies' reaction to the deed. 


\section{Utopia, anti-utopia and dystopia}

The utopian literary tradition can be traced back to Sir Thomas More's work Libellus vere aureus, nec minus salutaris quam festivus, de optimo reipublicae statu, deque nova insula Vtopiae (1516) - better known as Utopia - which described a society that appealed to the reader as a better yet unattainable alternative to Early Modern England. A widely contested concept, Levitas argues that "utopia is about how we would live and what kind of a world we could live in if we could do just that" (1). The imagining of a better alternative inevitably implies the necessary criticism of the present. As Kumar perfectly puts, "utopias have always aspired to be both critical and constructive" (23), and they achieve this through the distance that the imaginary societies offer. From More's time, countless authors have offered their view of alternative better places through this literary device. Classic modern utopias include Tommaso Campanella's City of the Sun (1606), Francis Bacon's New Atlantis (1626), but also Edward Bellamy's Looking Backward (1898), a utopia whose followers held as a blueprint and sought to implement. However, the practical application of the utopian ideal brought along a concern about its implications for individual freedom, sustainability, or the preservation of human nature.

The anti-utopia appeared as a means to oppose the optimism that many utopias embodied with regards to social change, order, and science. Thus, as optimism fostered social alternatives to the present, other authors pondered the possible negative consequences of the application of such ideas. Already in the 18th century we have an example of an anti-utopia, Jonathan Swift's Gulliver's Travels (1723). In his novel, and through piercing satire, Swift criticised the idea of humans as rational beings. The reasoning horses dismiss Gulliver's claims arguing that humans use their ability to increase their destructive power (Donnelly). At the same time, their society, guided by pure reason, disregards the importance of ethics in the resolution of problems. The scepticism towards technological advances of the industrial revolution and scientific progress brought along a growing concern about the negative extremes of those changes. Mostly considered an example of a gothic novel, Mary Shelley's Frankenstein, or, the Modern Prometheus (1818) is often thought to be "a satire on the failed aspirations of the [French] Revolution" (Claeys 110) and an inspirational source for the subsequent development of dystopian/science fiction. In particular, Shelley's text offers not only a nightmarish vision of the consequences of pursuing science without considering ethics, but also an introduction to the idea of an artificial new man, which would foster the development of posthumanism, a common theme in contemporary dystopias. 
In time, dystopian fiction developed as a literary genre which describes alternative societies that are comparatively worse than the one where the author is living. While utopian texts sought to criticise and construct, dystopias were designed as cautionary tales that built on current concerns and socio-political trends and extrapolated them to an alternative future to depict their consequences. This subgenre became widely popular in the 20th century, in the context of global conflicts and the rise of totalitarian regimes, with titles such as Yevgueni Zamyatin's We (1924), Aldous Huxley's Brave New World (1932), or George Orwell's Nineteen Eighty-Four (1949). Later on, in the 1980s, dystopias acquired a critical nature and were inspired by the socioeconomic context and the fear of historically oppressed groups to lose some of the recently acquired rights (Baccolini).

Utopian and dystopian literature may describe all kinds of ideology, including "socialist, capitalist, monarchical, democratic, anarchist, ecological, feminist, patriarchal, egalitarian, hierarchical, racist, left-wing, right-wing, reformist, free-love, nuclear family, extended family, gay lesbian," etc. (Sargent 21 ) and, therefore, may appeal to a wide variety of audiences. With the turn of the millennium, a new wave of dystopian fiction emerged. In this case, 21 st century dystopian fiction has blossomed among young readers, disenchanted with the economic, social, and political situation and a system that, some consider, has failed them (Brown, Lauder and Ashton 93). In fact, despite dystopian fiction's ingrained cautionary-tale nature, which propels readers into an imagined future whose underlying weaknesses and nightmarish structures are rooted in the present, contemporary dystopian novels offer invaluable insight into very palpable realities and the anxieties of their audiences. Gender, race, and environmental studies, among others, have increasingly seeped into the flux of research on this subgenre, analysing it not from the point of view of what it "could be", but rather as another cultural representation of what already "is" as the immediacy of the prophecies undergirds the narrations.

\section{Young-adult dystopias, gender and trauma}

While some dystopian fiction for young adults may be considered to focus excessively on topics of teenage anxiety, romance, or physical appearance, some of the most popular novels published in the late 2000s and early 2010s present multi-layered societies where societal structures permeate and define citizens' behaviour and where the absolute control exerted by the regimes over the characters forces readers into a state of permanent alert and criticism. In fact, the popularity of some of these novels both among youngsters and adults is partially the result of the fact that "these works speak to the greater human condition, and 
not just to the specific teenage experience" (García xi). For decades now, young adult fiction has represented delicate matters such as bullying, mental health, illness, or rape as problems that teenagers or young adults face in their lives (Cart). Teachers have taken advantage of the extreme popularity of so-called "problem novels" to introduce discussions in the classroom that revolve around those topics. In the case of dystopian fiction, the violence inherent to the totalitarian or highly structured societies in the novels has led to their incorporation into the curriculum, as research shows that reading them in high school or higher education allows students to draw parallels between the acts of violence in these novels and in real life while fostering students' interest in activism and politics (e.g., Simmons; Soares).

One of this new wave's characteristics is that most of the novels have female heroines as protagonists, which has drawn scholarly attention to the degree to which these novels challenge stereotypical gender roles and heteronormative romantic plotlines, that is, the extent to which they are the heirs of the feminist critical dystopias of the 20th century. Most of the criticism revolves around the romantic choices of the protagonists and the endings, which in many cases involve sacrifice or a traditional lifestyle (see Broad; Fritz; Jarvis; Burgos-Mascarell). Piotrowski and Rybakova include Divergent in their choice of texts to promote gender equality among teenagers; however, they do not analyse the text. Both of the novels analysed include acts of violence towards the female protagonists, but research on this issue has been sparce. Research on Veronica Roth's novels (20112013) has focused on the interaction between Tris, the protagonist, and her aggressors as an instance of bullying and on the effects this experience has on her ability to have fulfilling relationships with men (Lashley). While Lashley analyses the aggression in terms of bullying and bullied, she only refers to Tris' gender identity as a trait the bullies use to tease her. As for Across the Universe (Revis 2011-2013), virtually no studies have analysed the text except for a posthumanist analysis of the protagonist's body and identity at the end of the trilogy (McCulloch). To the best of my knowledge, no studies have focused on the representation of gender-based violence the protagonists of the two selected trilogies endure.

With dystopian fiction's popularity, it is paramount to ascertain whether the representations of violence against women are as transgressive as the heroines and to what extent they challenge real-life dynamics. Drawing on previous research on sexual abuse in young adult fiction (e.g., Altrows), the study focuses on societal silencing, victim-blaming, or victims' qualia and coping strategies. Trauma novel refers to "a work of fiction that conveys profound loss or intense fear on individual or collective levels" (Balaev 150). The event can include, among others, sexual 
violence, or the loss of a beloved person, and is thus not limited to collective traumatic circumstances. While dystopian fiction has typically focused more on the description of society, rather than on the individual's feelings (MartínezLópez), it could be argued that climate dystopian fiction, insofar as it deals with collective trauma resulting from environmental collapse, and recent dystopian fiction with a turn towards protagonist introspection (e.g., Butler's Parable of the Sower and YA dystopian fiction in general) are strongly connected with trauma narratives. Therefore, the critical approaches to literary trauma can be incorporated to analyse traumatic experiences in the novels analysed. According to Balaev, the protagonist embodies culture and the process of introspection that the traumatised character undergoes serves to analyse their relationship with the external world, its structures, and dynamics. In doing so, the characters' behaviour offers insight into the heterodoxy or orthodoxy of the novels' representation of sexual assault. The study introduces the novels' contexts and the incident that is to be analysed, followed by an analysis of the victims' reaction, a discussion on the role of culture, and an analysis of the aggressors.

\section{Structural violence}

In Across the Universe, Amy participates in a colonizing mission to CentauryEarth as the daughter of a general and a scientist and wakes up early from cryogenic sleep to discover a racially homogeneous society where most of the population are under chemical control and the few who are allowed to remain conscious - artists and writers - are confined to a hospital and its surroundings. The homogeneous physical appearance of the natives automatically marks Amy, with her red hair, green eyes, and pale skin, as "other," an outsider. She is mostly feared or distrusted, but some of the people around her-all of them male except for another intern in the hospital, Victria-warn her to be careful. "The doctor looks sceptical. 'You can, of course, 'run' whenever you'd like. But...' His gaze roves over me. 'It may not be advisable. You will stand out on board this ship... I cannot vouch for your safety when you leave the Hospital" (Across 100). She receives unwanted attention from one of the conscious men early on: "Seeing the way the tall man looked at me reminds me of the doctor's warning about leaving the Hospital" (Across 132).

The carefully scheduled lives of the inhabitants include a "season" in their fertile lives when they are hormonally prompted to copulate everywhere in order to secure the next generation, each of which is 25 years apart. This phenomenon is turbulent and dangerous because everybody is thought to be keen to participate, and nonconscious people-those who are under the influence of the mindcontrolling drug - do not discern between those who are and are not under 
chemical influence. In this vein, Harley reminds Amy that it is not safe to go outside during the season: "Harley hesitates. 'It's not safe. Not now" (Across 219). Amy resists the rules as she considers herself an independent person who shouldn't be more worried about going outside than other characters who happen to be male. In this context, she is assaulted by Luthe-man she was worried about - and some other nonconscious men participating in the season.

Luthe straddles me and rips my tunic off, curses at the undershirt I've been wearing in place of a bra, and rips it off, too. The tattered remains of my clothes pool at my arms, but my breasts are exposed. And even though I've seen half the crew of this ship walking around naked in a lovemaking haze, I am ashamed of my nudity. And terrified, (Across 221)

She is saved by Harley, and they escape. Both Harley and the male protagonist-Elder-seem to share a concern over the safety of their female friends: “"Hey, be careful out there. The Season's pretty wild right now.' I'm glad Amy's safe with Harley. Victria doesn't look at me. 'Luthe walked me over. Orion's here now; he can walk me back"' (Across 245). The narrative seems to focus mostly on women's protection and safe behaviours rather than on questioning the faulty system that enables the threat to exist and that highlights Amy's physical appearance as exotic and problematic.

The approach is fairly similar in Veronica Roth's Divergent trilogy with some nuances. In Divergent, the population in a future, post-apocalyptic Chicago is divided into factions according to their personality. At the age of sixteen, every citizen must decide whether they stay in their family's faction or be transferred in a public ceremony. The protagonist is Beatrice Prior (Tris), who moves from Abnegation, a humble and selfless faction, to Dauntless, a faction that praises extremely competitive and risk-prone behaviour and manages the city's defence forces. Thus, they endure highly strict military training. Trainees are expected to sever all their previous relationships, including their families. They are only allowed to see them once during the training and showing emotion towards them is considered a sign of poor adaptation to the selected faction. Therefore, transfers are isolated and can only rely on their peers in a context of high competition and aggressiveness. Unlike Amy, Tris is encouraged by the faction's culture to risk her life and train to be able to defend herself against any enemy within or outside her faction.

The training has three qualifying rounds, the first of which is purely physical and involves fighting other candidates until one is unconscious. As Tris is smallframed and has no previous training, she barely makes the cut. However, the second round involves mental ability to face fears. The candidates are injected 
with serums that trigger a simulation where they are forced to face nightmarish situations. for which Tris has an innate advantage. Her divergence, which means that she has abilities for all factions and can tell the simulations are not real, allows her to simply wake up by convincing herself that she is in a simulation. Like Amy, Tris is thus singled out as "other", even if nobody knows about her divergence, and becomes the target of envious and aggressive candidates who feel threatened by her quick improvement. When she is finally assaulted by a group of male candidates, her reaction differs from Amy's. Tris has been trained to face these situations, so she focuses on possibilities for escape and the identification of aggressors.

That voice is higher than the average male's and clearer. Peter. [...] I try to focus on the hand on my mouth. There must be something distinct about it that will make him easier to identify. His identity is a problem I can solve. I need to solve a problem right now, or I will panic. (Divergent 279)

What Tris is not prepared for, however, is the groping she endures. She, as a woman, is subjected to additional aggressions intended to denigrate her, both through unwanted touch and through the mockery of her body, commented upon as not womanly enough:

My feet leave the ground, and my attackers are the only thing keeping me from falling into the water. A heavy hand gropes along my chest. "You sure you're sixteen, Stiff? Doesn't feel like you're more than twelve. The other boys laugh." Bile rises in my throat and I swallow the bitter taste. "Wait, I think I found something!" His hand squeezes me. I bite my tongue to keep from screaming. More laughter. (279)

After the attack, we see that the focus is not on preventing more aggressions of the same sort by confronting and expelling the culprits, but, once again, on making sure the victim takes care of her own safety by modifying her habits or relying on others' protection. Her best friend asks directly: "Are you sure you should be running around here alone at night?" (Divergent 319). Her saviour and romantic interest requests her to look weak so that her friends protect her. She seems to question the idea but agrees: "And Four told me to rely on my friends. I don't know who I should rely on more, because I'm not sure who my true friends are. Uriah and Marlene, who were on my side even when I seemed strong, or Christina and Will, who have always protected me when I seemed weak?" (Divergent 294). Both Amy and Tris are victims of their culture, which shapes their responses to the attacks. 
Tris' culture is mostly military, highly masculine, and individualistic. In military institutions, where discipline and strong hierarchy are defining traits, the reporting of sexual assault is virtually non-existent (Reuters). In US military academies, when these crimes are reported, $48 \%$ of the victims experience retaliation (Van Winkle et al.). Furthermore, as teenagers are concerned, available figures of sexual harassment and bullying of girls by peers reaches $50 \%$ of surveyed women (Hill 14). As with adults in the military, very few victims report the crime, around 9\%. As in Tris' case, Amy's background is military. Her father is a general and she mentions repeatedly how she was taught how to use guns and defend herself, which she does once she recovers from the trauma: "I want you to know that I know where I can find a gun." "My father raised me to know what a gun is and how to use it." "I was raised with guns like a proper military brat; my father made sure I knew how to protect myself, to treat weapons as tools, not toys" (A Million 203).

Culture, as per Kirmayer, "influence[s] what is viewed as salient, how it is interpreted and encoded at the time of registration and, most important [...], what is socially possible to speak of and what must remain hidden and unacknowledged" (191). How and to whom the traumatic event is told is key because speaking about an aggression is considered to have cathartic properties. Particularly relevant are the victims' coping strategies and the narrative techniques employed to express her feelings. According to Altrows, the repetition of scenes of sexual abuse in young adult fiction, far from being a means to spark discussion and outrage, often serves to trivialise the aggression and falls in line with the postfeminist ideology, which seeks to individualise the experience of a group. In fact, postfeminism appears to extol women's capabilities, their independence and strength, while negating the established sociocultural structures that constrain their agency. It depoliticises citizens so that their struggles become individual concerns that each person must resolve, thus denying victims the possibility to take collective action. The western utopian impulse, Jameson has argued, seems to have ceased in the late 1970s or, perhaps, with the neoliberal politics of Reagan and Thatcher in the 1980s. He argues that the disillusionment with the multiple utopian movements of the 1960s brought along the incapability of imagining complex alternatives to the current socioeconomic system based on capitalism. The triumph of late capitalism implied the idea of a society that could not be perfected, where consumerism and neoliberalism were preferable to any other alternative. Thus, capitalist countries, particularly the USA, became a landmark of anti-utopianism. Similarly, in proclaiming that the aims of feminism are already accomplished, postfeminism is spreading an anti-utopian message that impedes further improvement by denying there is anything to improve in the first place. The approaches to self-sufficiency and the modification of one's behaviour to 
ensure their safety, as well as the reference to guns as a means to defend themselves as individuals are reminiscent of this ideology.

Furthermore, postfeminist examples of narrations of rape and similar experiences focus on the victim's qualia and the negative effects of the aggression on her psyche. The use of a first-person narrator may enhance readers' identification with the protagonist, thus promoting empathy and a more emotional response to the injustice suffered by the character. However, some scholars argue that this technique may also foster an excessively individualistic focus and the inevitable alienation of the victim from the demographic group that has shared the same experience, thus limiting political approaches to sexual abuse from the perspective of social realism (Hubler). To ascertain whether that is the case in the novels under study, the characters' coping strategies and the social response to the attack should be considered.

\section{Victims' coping and social response}

In Amy's case, the assault prevents her from carrying a normal life with the stressrelief activities that she used to cope with daily events, like jogging: "The room caves in around me. What I want to do is run, but I'm too afraid of what lurks in the dark, in the places where there's nothing but cows and sheep and no one to hear me shout for help" (A Million 163). Concerning her feelings, she experiences self-blaming thoughts that appear at least twice overtly. The first one refers to the immediacy of her sexual assault. The fact that she has required months to recover enough to be able to think, process and consider speaking about it seems inacceptable to her:

What am I supposed to say? That I still have nightmares about something that happened three months ago? How lame would that sound? If I was going to say something, I should have said it then. But then everything else became much more important. (A Million 56)

On the other hand, she underplays the relevance of the crime in the wider context of the uprising in the spaceship. Further along the novel we encounter a second instance of self-blaming. In this case, however, she focuses on the fact that the assault was a rape attempt and she managed to escape. Amy seems to heal progressively as she gives herself permission to feel the way she does, thus moving the focus away from her as a victim and towards Luthe as the aggressor: "I wrap my arms around myself, squeezing them tight against my body. Why should I be so afraid of him when he hasn't even really done anything? Is almost a good enough reason for fear? Yes" (A Million 163). In spite of the obvious evolution, she resists informing anybody of the attack. Only Harley knows about it because 
he rescued her; however, he is mentally unstable and commits suicide later in the first novel. The lack of a support grid and the context mentioned above plays an essential role, as she becomes an individual in a society from which she is isolated. The turning point will be the discovery of a fellow victim: Victria. After failing to rape Amy, Luthe attacks Victria, who is unfortunately unable to escape. Amy's reaction is immediately one of sorority, of reassurance in the face of shared trauma: “'This is a promise,' I tell her, squeezing her pinkie with mine. 'A promise that you don't have to be alone with this secret and pain anymore"" (A Million 202). As she realises that Luthe is a danger not only to her as an individual, but to other women, like Victria, Amy establishes a connection between the assault and society. It is Victria's narration what propels her into telling Elder, the leader of the colony, about both assaults:

I can't. It's too late. I can't change the past, and it will only upset him. I can't explain why I never told him before - a combination of being afraid to put what happened into words and being worried about what his reaction would be. I let too much time pass. Part of it was my faultI shouldn't have gone outside during the Season. And even though I know, logically, it's not my fault, it's his, I still can't forget [...]. Elder touches my hand. I flinch away. But then I remember how Victria shied away from me. And if I can't speak for myself, I can at least speak for her. (A Million 259).

In this paragraph, Amy goes through the whole process of healing, from selfblaming, dismissing it as less important or too shocking, considering it is too late, and physically shying away from contact to the connection she established with Victria.

There is one other instance where Amy remembers her experience and connects it to the dynamics of societies. In this case, however, the context is that of the new planet, where genetically enhanced workers are kept drugged, as in the ship. In this case, however, men in command of the colony regularly rape female workers who are unable to defend themselves. "The kind of men who had no problem turning people into mindless automatons would have no problem doing exactly what they wanted with the women, the women who could not even think to protest" (Shades 348). The text indicates that Amy is able to draw a comparison between the situation that the women of the colony endured as victims of rape and the assaults both Amy and Victria suffered on the spaceship, thus establishing herself as part of an oppressed group.

Tris' case is completely different. Her first decision is not to report the attack to her superiors. "'I could report this,' he says. 'No,' I reply. 'I don't want them to think I'm scared.' He nods. He moves his thumb absently over my cheekbone, 
back and forth. 'I figured you would say that." Only when Four, who saves her from the attack, requests her to look weak the following day, she explains the additional denigration.

The idea nauseates me. "I don't think I can do that," I say hollowly. I lift my eyes to his. "You have to." "I don't think you get it." Heat rises into my face. "They touched me." His entire body tightens at my words, his hand clenching around the ice pack. "Touched you," he repeats, his dark eyes cold. "Not ... in the way you're thinking." I clear my throat. I didn't realize when I said it how awkward it would be to talk about. "But ... almost." I look away. (Divergent 286)

She seems unable to find the right words and rejects the idea of sexual abuse, because the assailants ridiculed her body while groping her instead of considering it a source of pleasure, which is the traditional representation of this kind of sexual assault. Four and Elder's reactions to the aggression are very similar. Both become very still and are defined as tense or cold. However, neither of them exposes the criminals, either because of time constraints and responsibilities or because the victim requests it, as in Divergent. In this second case, the identity of the aggressors is relevant, as one of them is Tris' friend, Al.

According to Four, Al's motivation to participate in the attack is mainly that he felt threatened by her and the fact that she did not continue to fit into the gender stereotype of a small and fragile girl that needed his protection. The attack has been considered a consequence of the hypermasculine features of the male characters: "This sexually exploitative indicator of hyper-masculinity [...] is prompted by Tris's remarkable ability during initiation. These characters perceive her as a threat to their masculinity and position in the social hierarchy and attempt to assert their dominance by objectifying and intimidating her" (Seymour 644). However, it is worth considering that $\mathrm{Al}$ does not fall into the hypermasculine category, and he has been considered a victim of "gay bashing," even if he does not display this sexual orientation, because he lacks overtly "masculine traits" like fighting and being attractive (Lashley 171). In fact, being rejected by Tris is key to understand his participation in the attack. This reaction has been categorised as a compensation for the aforementioned effeminacy, but I argue that it is reminiscent of the behaviour and ideology behind "incels."

Involuntary Celibate (incel) individuals "assail what they believe are the social injustices wrought by genetic determinism and female preferences that have relegated them to the margins of society" (Hoffman, Ware, and Shapiro, 565). Although Al's thought process is not revealed, the attack happens after he is rejected by Tris. While the possibility of establishing a romantic connection with Tris existed, Al felt protective of her. However, once she makes it clear that she 
does not feel attracted to him, he feels resentful and is convinced by Peter and the other members of his group that she was just using him. Incel attacks are based on the idea that they need to "take control of their lives and exact revenge for the dismissive and derogatory way they were treated" (2). Incels believe that an elite of men attract average-looking and beautiful women, while average-looking men appeal to unattractive women, which means that incels or unattractive men do not attract any women. The key would be the fact that being rejected because of genetic characteristics, just like the ones that determine your personality and skills in the world of Divergent, leads Al to frustration and loneliness, as Tris is the only single girl in their social group.

Finally, the reaction of Tris' friends to the fact that $\mathrm{Al}$ participated in the attack is one of disbelief. Most victims fear not being believed when they tell their personal experiences of sexual abuse (Alaggia and Wang). Tris' closest friend, Christina, questions Tris' version that Al was among the assailants: "“Al, though? Are you sure, Tris?' I stare at my plate. I'm the next Edward. But unlike him, I'm not going to leave. 'Yeah,' I say. 'I'm sure'” (Divergent 292). Tris immediately thinks of Edward, another transfer who is brutally attacked in his sleep and leaves the faction lest someone kills him. The fact that Tris indicates that she will not leave may be read as self-confidence or as indication that she is willing to take the risk of being murdered to remain part of the community. On the other hand, Will, another friend, blames Al's behaviour on frustration and argues he is not the same person lately, which serves to dissociate a male character capable of murder from his friend, thus contributing to the narrative of "sick men" or mental derangement. “"It has to be desperation,' says Will. 'He's been acting...I don't know. Like a different person."' (292)

On the other hand, the trilogy shows us Tris reluctantly allowing Peter, who organized the aggression, to partake in the rebellion with her and her friends. Far from being judged for his crimes, the ending of the trilogy shows him freely deciding that he doesn't want to remember his actions, which he considers define him as an evil person that cannot be redeemed or changed. With this decision, the aggressor determines his own punishment, as did Al by committing suicide, and has a second chance that the victim cannot obtain for herself. In contrast, in Across the Universe, Luthe finds death by an unknown character through the use of medical patches. Amy finds him on the floor and decides to eject his body from the ship. While Luthe was not tried for his deeds, his death is a representation of personal revenge and compensates - albeit in an uncivilized way-the tragedy the women have endured. 


\section{Conclusion}

The popularity of young adult dystopian fiction over the past couple of decades has fostered analysis of the most popular texts from a myriad of perspectives including gender. However, and despite feminist attempts at highlighting the persistence of sexual crimes against women through movements such as \#metoo, research had not yet explored the representation of these crimes in YA dystopias. This study presents an introductory analysis of two dystopian fiction trilogies for young adults - Veronica Roth's Divergent and Beth Revis' Across the Universewhere the protagonists endure sexual abuse as the main attack or as an additional derogatory act associated to their being females. In both cases, the sexual abuse is neither made public nor reported to the authorities. In Tris' case, she explains the attack to her friends but omits the sexual part, deciding that it is humiliating and would make her look even weaker. On the other hand, Amy remains silent until she establishes an emotional connection with another victim. While both protagonists offer postfeminist approaches to safety by stressing the importance of guns or fighting skills, Amy is able to criticise the social structures that enable sexual assaults to persist as a constant threat to women in the dystopian society they inhabit.

The novels seem to challenge some of the most common gender stereotypes associated with heroines; however, sexual aggressions remain unpunished, as in Divergent, where the aggressors choose their own fate, or are punished through individual action or revenge outside of formal law mechanisms, as in Across the Universe. Furthermore, in Divergent, the leader of the aggressors, Peter, is even allowed to partake in collective action and to obtain a second chance after confessing himself purely evil. His decision to erase his own memories prevents fair punishment and denies the victim the right to confront him in the future. Not only does this denial represent an additional contribution to the efforts to deprive protagonists from their agency, but it also normalises sexual assault as a plot resource, which can lead to woman readers' disempowerment (Reid and Finchilescu).

Regarding the profiles of the criminals, Amy's aggressor, Luthe, represents an animalistic take on sexual predators, whereby the pray can be any woman he encounters, whereas Tris' friend Al aligns with the fact that most cases of abuse are enacted by people the victim knows well. Furthermore, this character's behaviour agrees with recent problematic emergence of incel violence. Even so, the aggressor or necessary collaborator is victimised, and Tris' friends try to find a logical explanation for Al's behaviour.

All in all, the community fails to offer the victims its support after the crime and the promise of structural change that would prevent the repetition of the 
assaults. In fact, the individualisation of the attacks is reminiscent of the postfeminist ideology that demands that everyone oversee their own safety while denying the existence of societal structures that reinforce behaviours such as violence towards women. Only Amy's relationship with a fellow victim offers some hope and a critical approach to sexual assault in the novels. The analysis suggests that tepid criticism of sexual assault may still be present in novels that are considered to stimulate critical thinking among their readers. Therefore, and since the analysis focused exclusively on two trilogies written by white American women, it would be interesting to examine whether YA dystopian novels by other US and non-US authors offer different approaches to sexual assault, including, if not prevention, then, at least, a just punishment. On the other hand, future research could involve a reader-response analysis of the two novels among young woman readers to determine the possible disempowering effect these representations may have on readers that belong to the victims' collective: women.

\section{WORKS CITED}

Alaggia, Ramona, and Susan Wang. "I Never Told Anyone until the \#Metoo Movement:" What Can We Learn from Sexual Abuse and Sexual Assault Disclosures Made through Social Media? Child Abuse \& Neglect, vol.10, 104312, 2020. DOI: https://doi.org/10.1016/j.chiabu.2019.104312

Altrows, Aiyana. "Silence and the Regulation of Feminist Anger in Young Adult Rape Fiction. Girlhood studies, vol. 12, no. 2, 2019, pp. 1-16. DOI: https://doi.org/10.3167/ghs.2019.120202

Baccolini, Raffaella. "Introduction." Dark Horizons: Science Fiction and the Dystopian Imagination. Eds. Raffaella Baccolini and Tom Moylan, Routledge, 2003, pp. 1-12.

Bacon, Francis. New Atlantis. 1627. Project Gutenberg. 2008.

Balaev, Michelle. "Trends in Literary Trauma Theory." Mosaic: A Journal for the Interdisciplinary Study of Literature, vol. 41, no. 2. 2008, pp. 149-66. https://www.jstor.org/stable/44029500

Bellamy, Edward. Looking Backward: 2000-1887. 1898. Braille Writers' Association of Victoria, 1925.

Broad, Katherine R. “"The Dandelion in the Spring': Utopia as Romance in Suzanne Collins's The Hunger Games Trilogy.” Eds. Balaka Basu, Katherine R. Broad and Carrie Hintz. Contemporary Dystopian Fiction 
for Young Adults. Routledge, 2014, pp. 117-30. DOI: doi: $10.4324 / 9780203084939$

Brown, Phillip, Hugh Lauder and David Ashton. The Global Auction: The Broken Promises of Education Jobs and Incomes. Oxford University Press, 2011.

Burgos-Mascarell, Andrea. "The influence of Culture on dystopian heroine's choices: a vindication of their right to decide." CAUCE. Revista Internacional de Filología, Comunicación y sus Didácticas, vol. 42, 2019, pp. 25-44.

Campanella, Tommaso. The City of the Sun. 1606. Cosimo, Inc., 2007.

Cart, Michael. Young Adult Literature: From Romance to Realism. American Library Association, 2016.

Claeys, Gregory. "The Origins of Dystopia." The Cambridge Companion to Utopian Literature. Ed. G. Claeys. Cambridge University Press, 2010.

Donnelly, Dorothy F. 'Utopia and Gulliver's Travels: Another Perspective." Moreana, vol. 25, no. 1, 1988, pp. 115-24. DOI: https://doi.org/10.3366/more.1988.25.1.21

Fritz, Sonya Sawyer. "Girl Power and Girl Activism in the Fiction of Suzanne Collins, Scott Westerfeld, and Moira Young." Female Rebellion in Young Adult Dystopian Fiction. Eds. S. Day, M. Green-Barteet, \& A. Montz. Ashgate Publishing, Ltd., 2014, pp. 17-31.

García, Antero. Critical Foundations in Young Adult Literature: Challenging Genres, Volume 4. Sense Publishers, 2013.

Hill, Catherine, and Holly Kearl. Crossing the Line: Sexual harassment at School. Washington, DC: AAUW, 2011.

Hoffman, Bruce, Jacob Ware, and Ezra Shapiro. “Assessing the Threat of Incel Violence." Studies in Conflict \& Terrorism, vol. 43, no.7, 2020, pp. 56587. DOI: https://doi.org/10.1080/1057610X.2020.1751459

Hubler, Angela E. "It Is Not Enough to Speak: Toward a Coalitional Consciousness in the Young Adult Rape Novel." Children's Literature, vol. 45, no. 1, 2017, pp. 114-37. DOI: $10.1353 / \mathrm{chl} .2017 .0006$

Huxley, Aldous. Brave New World. 1991. Ed. R. Southwick. Longman, 1932.

Jameson, Fredric. “An American Utopia.” An American Utopia: Dual power and the Universal Army, 2016, pp. 1-96.

Jarvis, Christine. "How to Be a Woman:

Models of Masochism and Sacrifice in Young

Adult Fiction. Popular Culture as Pedagogy: Research in the Field of 
Adult Education. Eds. Kaela Jubas, Nancy Taber, and Tony Brown. Sense Publishers, 2015, pp. 134-50. DOI: 10.1007/978-94-6300-274-5_9

Kirmayer, Laurence. "Landscapes of Memory." Tense past: Cultural essays in Trauma and Memory. Routledge, 1996, pp. 172-98.

Kumar, Krishan. Utopia and Anti-Utopia in Modern Times. Basil Blackwell, 1987.

Lashley, Katherine. "Dauntless Bullying in Veronica Roth's Divergent." Bullying in Popular Culture: Essays on Film, Television and Novels. Ed. Abigail G. Scheg. McFarland \& Company, 2015, pp. 164-75.

Levitas, Ruth. The Concept of Utopia, Volume 3. Peter Lang, 2010.

Martínez López, Miguel. “Defining English Utopian Literature: Origins, Problems for the Reader, and Some Twentieth-Century Manifestations." Dreams and Realities: Versions of Utopia in English Fiction from Dickens to Byatt. Universidad de Almería, 1997.

McCulloch, Fiona. “"No Longer Just Human:' The Posthuman Child in Beth Revis's Across the Universe Trilogy." Children's Literature Association Quarterly, vol. 41, no. 1, 2016, pp. 74-92.

Orwell, George. Nineteen Eighty-Four. 1949, Penguin Modern Classics, 2000.

Piotrowski, Amy, and Katie Rybakova. "Reading Adolescents in Dystopian YAL through the Lens of Feminism." GALA Journal: A Journal of the Gender in Literacy and Life Assembly, vol. 21, 2015, pp. 23-30.

Reid, Penny, and Gillian Finchilescu. "The Disempowering Effects of Media Violence against Women on College Women." Psychology of Women Quarterly, vol.19, no. 3, 1995, 397-411. DOI: 10.1111/j.14716402.1995.tb00082.x

Reuters. "U.S. Military Sexual Assaults Down as Reports Reach Record High." Reuters, 2017, https://www.reuters.com/article/us-usa-militarysexualassault/u-s-military-sexual-assaults-down-as-reports-reachrecord-high-idUSKBN17X2CF Accessed 15 Dec. 2021.

Revis, Beth. Across the Universe. Penguin UK, 2011.

---. A Million Suns. Penguin UK, 2012.

---. Shades of Earth. Penguin UK, 2013.

Roth, Veronica. Divergent. Katherine Tegen Books, 2011.

---. Insurgent. Katherine Tegen Books, 2012.

---. Allegiant. Katherine Tegen Books, 2013. 
Sanghani, Radhika. "The Dark Truth about Sexual Harassment in our Armed Forces." The 2015, https://www.telegraph.co.uk/women/womens-life/11751718/Sexualharassment-in-the-UK-Armed-Forces-The-dark-truth.html Accessed 15 Dec. 2021.

Sargent, Lyman Tower. Utopianism: A very Short Introduction, Volume 246. Oxford University Press, 2010.

Seymour, Jessica. “"Murder Me... Become a Man:' Establishing the Masculine Care Circle in Young Adult Dystopia." Reading Psychology, vol. 37, no. 4. 2016 , pp. 627-49.

DOI: https://doi.org/10.1080/02702711.2015.1105336

Shelley, Mary. Frankenstein; or, The Modern Prometheus. 1818. Eds. David Lorne MacDonald and Kathleen Scherf. Broadview Press, 2012.

Simmons, Amber M. "Class on fire: Using the Hunger Games Trilogy to Encourage Social Action." Teaching towards Democracy with Postmodern and Popular Culture Texts. Eds. Patricia Paugh, Tricia Kress, and Robert Lake. Brill Sense, 2014, pp. 77-95.

Soares, Michael Arthur. "Here's Looking at You Kids: The Urgency of Dystopian Texts in the Secondary Classroom." Worlds Gone Awry: Essays on Dystopian Fiction. Eds. John J. Han, Clark C. Triplett, and Ashley G. Anthony. McFarland, 2018, pp. 210-24.

Swift, Jonathan. Travels Into Several Remote Nations of the World: In Four Parts. By Lemuel Gulliver, First a Surgeon, and Then a Captain of Several Ships.... Benj. Motte, at the Middle Temple-Gate in Fleet-Street, 1726.

The United States Department of Justice. https://www.justice.gov/ovw/sexualassault Accessed 15 Dec. 2021.

Van Winkle, Elizabeth P., and Maia M. Hurley. "2016 Service Academy Gender Relations Survey: Overview Report,” 2017.

Williams, Joyce. "Rape culture.” The Blackwell Encyclopedia of Sociology, 2007.

Zamyatin, Yevgeny. We. 1924. Random House, 2010.

Received September 302021

Revised version accepted December 152021 
